\title{
Preparation of Ti-Al-Si Alloys by Powder Metallurgy
}

Anna Knaislová, Pavel Novák, Filip Průša

Department of Metals and Corrosion Engineering, University of Chemistry and Technology Prague. Technická 5, 16628

Prague. Czech Republic. E-mail: knaisloa@vscht.cz

Ti-Al-Si alloys are very prospective materials for many applications, particularly for automotive and aerospace industry, due to their low density, excellent resistivity to oxidation and heat stability. The main problem is high brittleness at room temperature and high mechanical characteristics persisting only up to $800{ }^{\circ} \mathrm{C}$, which is limiting in some applications. Ti-Al-Si alloys were prepared by powder metallurgy using Self-propagating High-temperature Synthesis (SHS), which is considered as a first step in production consisting of SHS, milling and consolidation by Spark Plasma Sintering. In this experiment the observed subject was the microstructure and phase composition of Ti-Al-Si alloys in order to find optimum alloy composition for desired technology. Based on the results of this work, TiAl15Si15 alloy can be recommended due to fine microstructure composed of titanium silicide (TisSi3) particles in the matrix of titanium aluminide (TiAl). Concerning the production by SHS, the highest achievable heating rate can be recommended.

Keywords: Intermetallics, Powder Metallurgy, Reactive Sintering

\section{Acknowledgement}

This research was financially supported by Czech Science Foundation, project No. P108/12/G043.

\section{References}

[1] NOVÁK, P., PRŮŠA, F., ŠERÁK, J., VOJTĚCH, D., MICHALCOVÁ, A. (2009). Oxidation resistance and thermal stability of Ti-Al-Si alloys produced by reactive sintering. In: Metal.

[2] GUAN, Z.Q., PFULLMANN, T., OEHRING, M.,BORMANN, R. (1997). Phase formation during ball milling and subsequent thermal decomposition of Ti-Al-Si powder blends. In: Journal of Alloys and Compounds, 252, 12, pp. 245-251.

[3] WU, J.S., BEAVEN, P.A.,WAGNER, R. (1990). The Ti3(Al, Si) + Ti5(Si, Al)3 Eutectic Reaction in the Ti-Al-Si system. In: Scripta Metallurgica et Materialia, 24, 1, pp. 207-212.

[4] NOVÁK, P., VOJTĚCH, D., ŠERÁK, J., KUBÁSEK, J., PRŮŠA, F., KNOTEK, V., MICHALCOVÁ, A., NOVÁK, M. (2009). Syntéza intermediálních fází systému Ti-Al-Si metodou reaktivní sintrace. In: Chemické listy 103, 1022-1026.

[5] ZEMČÍK, L., DLOUHÝ, A., KRÓL, S.,PRAŻMOWSKIC, M. (2005). Vacuum Metallurgy of TiAl Intermetallics. In: Metal.

[6] MORSI, K. (2001). Review: reaction synthesis processing of Ni-Al intermetallic materials. In: Materials Science and Engineering: A, 299, 1-2, pp. 1-15.

[7] VYSTRČIL, J., NOVÁK, P.,MICHALCOVÁ, A. (2015). Preparation of Ultra-Fine Grained Alloys Based on FeAl-Si And Ti-Al-Si Intermetallic Compounds by Powder Metallurgy Using the Mechanical Alloying. In: Manufacturing Technology, Vol. 15, No. 2, pp. 238-242.

[8] VALALÍK, M., NOVÁK, P., KUBATÍK, T.F.,VOJTĚCH, D. (2015). Unconventional Method of Preparation Intermetallic Phases Fe-Al by Mechanical Alloying in Comparison to Reactive Sintering. In: Manufacturing Technology, Vol. 15, No. 1, pp. 105-109.

[9] NOVÁK, P., MICHALCOVÁ, A., ŠERÁK, J., VOJTĚCH, D., FABIÁN, T., RANDÁKOVÁ, S., PRŮŠA, F., KNOTEK, V., NOVÁK, M. (2009). Preparation of Ti-Al-Si alloys by reactive sintering. In: Journal of Alloys and Compounds, 470, 1-2, pp. 123-126.

[10] ALMAN, D.E. (2005). Reactive sintering of TiAl-Ti5Si3 in situ composites. In: Intermetallics, 13, 6, pp. 572579. 